$$
\text { CONF }-850310--2
$$

\title{
MAGNETOHYDRODYNAMIC CONSIDERATIONS FOR THE
}

$$
\text { DESIGN OF SELF-COOLED LIQUID-METAL }
$$

$\begin{array}{cc}\text { FUSION RFACTOR BLANKETS* } & \text { CONF-850310--2 } \\ \text { Basil F. Pi cologlou } & \text { DE85 } 000242 \\ \text { Argonne National Laboratory } & \end{array}$

During the course of the Blanket Comparison and Selection Study, magnetohydrodynamic effects were shown to present not only an efficiency but also a feasibility issue for self-cooled liquidmetal blankets, especially for tokamak machines. Based on stateof-the art MHD analyses and understanding of related phenomena, designs for both mirror and tokamak machines were developed. Although details of the designs depend on specific reactor parameters, MHD related considerations were the main driver in the development of the designs. This paper presents, in a unified way, these considerations, as well as effective strategles to minimize adverse MHD effects so that they can be used as guidelines by others in future design efforts.

Self-cooled liquid-metal blankets are attractive, compared to other blanket concepts, because of their inherent simplicity and favorable operating characteristics. The major challenge in the design of liquid-metal blankets stems from the interaction of the moving liquid-metal coolant/breeder with the large magnetic flux densities required for plasma confinement. This interaction results in induced electromotive forces, which drive currents mainly through the conducting duct walls. These currents also flow through the liquid metal and result in large body forces opposing the liquid motion. Large driving pressures are needed to overcome these body forces. These pressures not only affect plant efficiency because of the potentially high parasitic coolant pumping power, but may result in unacceptably high stresses within the duct walls. Simply increasing the wall thickness to reduce the stress is fruitless, because such an increase causes a decrease in electrical resistance, an increase in current, and a further increase in pressure. The problem is exacerbated by the fact that relatively high velocities are required to cool the first wall. The high velocities are needed to compensate for the reduction in heat transfer, caused by the suppression of turbu-

* Work supported by the U.S. Department of Energy/Office of Eusion Energy

\footnotetext{
The submitted manuscript has been authored by a contractor of the U.S. Governmen under contract No. W.31-109.ENG-3B. Accordingly, the $U$. S. Government retains a Accordingly, the U. Sovernent requs a nonexclusive. rover or reproduce the published form at inis contribution, or allow others to do so, ior
U. S. Government purposes.
} 
lence by the magnetic fleld. If the high velocities were to be transverse to the large toroldal fleld the pressure drop would be unacceptably high.

A solution to these problems, for the tokamak reactor, requires that the high velocity coolant channels be alignea with the large toroldal fleld, and that the rewaining ducts, which are by geometrical necessity transverse to the toroldal field, be made as large as possible. In addition, the wall thickness of the ducts 1s decreased and the effective duct sizes are increased in the low pressure, downstream side. Liquid-metal-cooled design can be improved significantly, if laminated construction with electrically insulating middle layers or electrically insulating coatings on the inner duct surfaces are employed. The use of such Insulators both decouples the pressure bearing structure from the MHD pressure drop, and reduces significantly (in the case of Insulating coatings dramatically) the coolant pressure.

These strategies for dealing with MaD-related design problems must be carried out with due consideration to 3-D MHD effects, so that design solutions, introduced to deal with one aspect of the problem, do not cause additional 3-D effects, and thus undesirable additional pressure drops and flow nonuniformities. Although detailed analyses of $3-D$ effects exist only for a very few cases, a simple circuit model can be used to help in the evaluation of design options and formulation of desirable design configurations.

The purpose of this paper is to present this model and related MHD facts in a concise form, intended for the designer, and to illustrate their use in evaluating and guiding the design process. The model is also used to derive quantitative functional requirements for both laminated structures ard insulating coatings. The functional requirements indicate that further substantial improvements in blanket design and performance axe technically feasible.

\section{DISCLAIMER}

This report was prepared as an account of work sponsored by an agency of the United States Government. Neither the United States Government nor any agency thereof, nor any of their employees, makes any warranty, express or implied, or assumes any legal liability or responsibility for the accuracy, completeness, or usefulness of any information, apparatus, product, or process disclosed, or represents that its use would not infringe privately owned rights. Reference herein to any specific commercial product, process, or service by trade name, trademark, manufacturer, or otherwise does not necessarily constitute or imply its endorsement, recommendation, or favoring by the United States Government or any agency therenf. The views and opinions of authors expressed herein do not necessarily state or reflect those of the United States Government or any agency thercof. 